DOI https://doi.org/10.30525/978-9934-588-80-8-2.35

\title{
ОСОБЛИВОСТІ ОРГАНІЗАЦІЇ ДОЗВІЛЛЯ СТУДЕНТІВ У ПОЗАНАВЧАЛЬНІЙ ДІЯЛЬНОСТІ
}

\author{
Данильченко О. Д. \\ аспірант кафедри педагогіки, професійної освіти \\ та управління освітніми закладами \\ Житомирський державний університет імені Івана Франка \\ м. Житомир, Україна
}

На сучасному етапі в умовах науково-технічного прогресу, стрімкого розвитку суспільства й реформування вищої освіти України стан здоров'я студентської молоді є пріоритетним напрямом молодіжної політики нашої держави. У Законі України «Про фізичну культуру i спорт» зазначається, що фізичне виховання різних груп населення напрям фізичної культури, пов'язаний із процесом виховання особи, набуттям нею відповідних знань і вмінь, із використанням рухової активності для всебічного розвитку, оздоровлення та забезпечення готовності до професійної діяльності й активної участі в суспільному житті [2].

Сьогодні надзвичайно важливою $є$ проблема формування та впровадження культури дозвілля студентської молоді. Діапазон дозвіллєвих інтересів студентів досить широкий, але в ньому переважають пасивноспоглядальні форми. Творчо-активні форми дозвіллєвої діяльності у студентів мають другорядне значення.

Основні причини такої усталеної спрямованості проведення часу:

- нерозвинена соціально-культурна інфраструктура (особливо в сільській місцевості);

- відсутність у значної частини молоді сформованої культури дозвілля;

- недостатність кваліфікованих спеціалістів у сфері педагогіки дозвілля;

- байдуже і некритичне ставлення молоді до свого дозвілля.

«Дефіцит культури», низький культурний рівень молоді негативно впливає на іiі духовний розвиток і врешті-решт - гальмує процеси реформування всіх сфер життєдіяльності суспільства.

Зроблений теоретичний аналіз за темою дослідження дає можливість зазначити, що фізичне виховання у вищих навчальних закладах викладається протягом усього періоду навчання студентів $\mathrm{i}$ 
здійснюється за такими формами: навчальна робота; робота в позанавчальний час; самостійна робота. Ці форми навчально-виховної роботи повинні функціонувати в міцній взаємодії, вони взаємопов'язані, доповнюють одна одну і являють собою єдиний процес фізичного виховання студентів. Навчальні заняття є основною формою фізичного виховання у вищих навчальних закладах. Кожне заняття, незалежно від розв'язуваних специфічних завдань фізичного виховання, підпорядковується загальним цілям морального, розумового, естетичного й трудового виховання. У позанавчальний час практикуються ранковий біг, гімнастика, фітнес, степ-аеробіка, йога, різні фізкультурно-масові та спортивні заходи. Не втрачають своєї популярності улюблені всіма види спорту, такі, як футбол, волейбол, хокей, плавання і т.п.

Проблема підвищення рівня здоров'я сучасної молоді, пропаганда фізичної культури й спорту, демонстрація їх можливостей щодо формування здорового способу життя - важливі чинники, що сприятимуть популяризації фізкультурних знань із метою переконання молодої людини в необхідності ії участі в позанавчальних фізкультурнооздоровчих заходах. У контексті дослідження означеної проблеми важливо розуміти причини негативного ставлення студентства до відвідування занять фізкультурної та спортивної спрямованості. До того ж маємо дані дослідження Н. Корж щодо причин, які знижують відвідуваність таких занять, серед яких - застосування на заняттях одноманітних вправ, низький емоційний фон занять, необхідність застосовувати вольові зусилля, небажання постійно носити спортивну форму [3]. Це свідчать про те, що в студентів не сформовані цінності фізичної культури, низька мотивація та неусвідомлення значущості занять із фізичного виховання.

Отже, однією з головних проблем організації позанавчальних занять iз фізичного виховання у ВНЗ залишається недостатня мотивація студентів до такого виду діяльності. Звідси перед ученими постає питання пошуку інноваційних підходів до планування й організації більш цікавих занять, розроблення науково обгрунтованого програмнометодичного забезпечення, що в сукупності сприятиме підвищенню інтересу студентів, зацікавленості в руховій активності, що забезпечує міцне здоров'я, кращий фізичний та емоційний стан студентства. Альтернативу «нудним» заняттям становить фітнес. Позитивні емоції, які отримує студентство в процесі непримусових цікавих позанавчальних занять фізичного виховання, позитивно впливають на працездатність студента, його функціональний стан і психолого-емоційну сферу особистості. 
Сьогодні особливої популярності набувають заняття функціональним тренінгом, які дають змогу задіяти велику кількість м'язових груп, усвідомлено виконувати фізичні вправи в поєднанні з дихальними та здатні значно підвищити рівень їхньої фізичної підготовленості. Такі заняття 3 використанням спеціального обладнання: степ-платфори, Core-платформи, гумові напівсфери, слайд-платформи, спрямовані на розвиток сили, гнучкості й координаційних здібностей студенток. Усе частіше впроваджуються в позанавчальну роботу 3 фізичного виховання студентів фітнес-програми із циклу Mind\&Body, до яких належать заняття за системою пілатес, різноманітні напрями фітнесйоги, каланетику, стрейчинг, нетрадиційні системи єдиноборств.

До речі, наукові дослідження, проведені американськими вченими, показали, що степ-аеробіка незамінна для профілактики й лікування таких недуг, як артрит й остеопороз, вона також корисна не тільки студентам, але й спортсменам у періоди підготовки до змагань i відновлення після травм.

Установлено, що за час тренування степ-аеробікою «спалюється» більше калорій, ніж під час тренувань танцювальної аеробіки. Однак $є$ й невід'ємний мінус: степ-аеробіка перевантажує колінні й тазостегнові суглоби. А це ризик травми для тих, хто страждає від нестачі кальцію. Безумовно, серед ефективних засобів пропаганди фізичної культури й спорту, що є запорукою формування здорового способу життя молодої людини, є наочне оформлення спортзалів; відкриті змагання, конкурси, турніри; популяризація різних видів спорту й фізкультурно-оздоровчих заходів за допомогою радіогазети, стіннівки; церемонія змагань із запрошенням олімпійських чемпіонів тощо; оформлення куточків спортивних досягнень студентства ВНЗ; фізкультурні паради й показові виступи кращих спортсменів ВНЗ; організація оздоровчих i спортивних таборів тощо.

Спираючись на зроблений теоретичний аналіз, визначено, що найвищої ефективності у формуванні естетико-фізичних якостей студентів можна досягнути за умови комплексного використання компонентів естетичного й фізичного виховання, а також загальних, специфічних і спільних засобів цих видів виховання [1].

Отже, можна стверджувати, що позанавчальна робота $є$ благотворним середовищем гармонійного й усебічного розвитку особистості студента, формування його професійного та індивідуального іміджу. Організація позанавчальної роботи з фізичного виховання за експериментальною програмою, залучення студентської молоді до різноманітних заходів, змагання, конкурси, конференції тощо, на нашу думку, сприятимуть формуванню та розвитку естетико-фізичних якостей студентів 
класичного університету в органічній єдності мотиваційно-ціннісного, художньо-спортивного й творчо-діяльнісного компонентів. Перспективи подальших досліджень. Перспективи подальшої роботи будуть спрямовані на дослідження та аналіз результатів упровадження експериментальної програми в процес фізичного виховання класичного університету для формування естетико-фізичних якостей студентів.

\title{
Література:
}

1. Бутенко М.В. Формирование культуры здорового образа жизни личности студента в процессе занятий атлетической гимнастикой : автореф. дисс. ... канд. пед. наук : 13.00.04. Б. : 2004. 22 с.

2. Про фізичну культуру i спорт : Закон України. Відомості Верховної Ради України (BBP). 1994. № 14. URL: zakon2.rada.gov.ua/ laws/ show/3808-12.

3. Корж Н.Л. Формування ціннісного ставлення у студентів до фізичної культури в процесі самостійних занять : автореф. дис. ... канд. наук 3 фіз. вих. і спорту : 24.00.02. Д., 2016. 21 с.

DOI https://doi.org/10.30525/978-9934-588-80-8-2.36

\section{USING A QUEST ROOM TO CREATE NATURAL COMMUNICATION CONDITIONS FOR TEACHING ENGLISH TO FOREIGN ARCHITECTURE STUDENTS}

\author{
Dragomyretska O. O. \\ Senior Lecturer at the Language Department \\ of the Training Center for Foreign Students \\ Odessa State Academy of Civil Engineering and Architecture \\ Odessa, Ukraine
}

Foreign university students in Ukraine have the possibility to study in English. This program exists for foreign non-native English speakers who have mastered English sufficiently to enter university. To promote the students' further development of their language skills, new methods for teaching English to foreigners who study and live in non-English environments are needed. Thus, a made-up language environment is needed to train student language skills. In the last five years, quest rooms (also known as escape rooms and reality quests) have become a popular new fun activity among youth. The aim of escape game is uniting a team through a common 